\title{
Clinical Characteristics of Preterm Neonates with Aggressive Posterior Retinopathy of Prematurity
}

\author{
Nancy Abdel Salam Gomaa' \\ Youssef AH Helmy ${ }^{2}$ \\ Sara Maher ${ }^{2}$ \\ Dina Hassanein $\mathbb{D}^{2}$ \\ Asmaa Shuaib ${ }^{2}$ \\ Ahmed I Hegazy ${ }^{2}$ \\ Aliaa A Ali $\mathbb{D}^{\prime}$ \\ 'Department of Pediatrics, Faculty of \\ Medicine, Cairo University, Cairo, Egypt; \\ ${ }^{2}$ Department of Ophthalmology, Faculty \\ of Medicine, Cairo University, Cairo, \\ Egypt
}

Correspondence: Aliaa A Ali Department of Pediatrics, Faculty of Medicine, Cairo University, Cairo

University Specialized Pediatric Hospital,

I Ali Basha Ibrahim Street, Giza, Cairo,

II562, Egypt

Tel +20100III I56II

Email draliaaadel@yahoo.com
Purpose: We aimed to identify the risk factors that may predispose preterm neonates to develop aggressive posterior retinopathy of prematurity (APROP).

Methods: This retrospective case control study included 16 infants with APROP in zone 1 or posterior zone 2 . Thirty-four gestational age and birth weight-matched controls with stage 2 or less ROP were included. We reviewed medical records on infant birth and postnatal characteristics.

Results: Patients who developed APROP had a significantly longer duration of caffeine therapy, were significantly more likely to be small for gestational age (SGA), and were more likely to have a positive blood culture than patients who developed less severe ROP. Patients with APROP who required retreatment had received inotropes for a longer duration of time, had received more plasma transfusions, were more likely to have IVH, and had a greater decrease in the serum hemoglobin during hospitalization.

Conclusion: Being SGA, receiving caffeine for a longer duration, and having cultureproven sepsis were associated with APROP. IVH, a low serum hemoglobin, the need for more plasma transfusions, and a longer duration of inotropes were associated with APROP which required retreatment.

Keywords: aggressive posterior retinopathy of prematurity, caffeine, dopamine, preterm neonate, small for gestational age

\section{Introduction}

Retinopathy of prematurity (ROP) is a major cause of childhood blindness in premature infants. Prematurity and excess oxygen therapy are well documented risk factors for ROP. ${ }^{1}$ Neonatal morbidities, such as bronchopulmonary dysplasia (BPD), necrotizing enterocolitis (NEC), intraventricular hemorrhage (IVH), and sepsis have been linked to ROP. ${ }^{2}$ The pathophysiology of ROP is characterized by an initial phase of vaso-obliteration, followed by a secondary phase of compensatory abnormal angiogenesis toward the vitreous of the retina (preretinal neovascularization). ${ }^{3}$

The term aggressive posterior ROP (APROP) is used to describe the severest form of ROP. ${ }^{4}$ APROP is characterized by its posterior location; either observed in zone 1, near the optic disc, or in posterior zone 2, evident neovascularization together with plus disease, and rapid progression. ${ }^{4}$ Rapid intervention may prevent blindness, but the overall response to therapy and prognosis has been poor, especially when APROP is detected in zone $1 .^{5}$ Therefore, the main goal is to diagnose eyes prone to reach APROP, when plus disease is minimal, or only preplus. 
Excluding fine vessel neovascularization of APROP is very important and requires a high-quality exam and a meticulous pattern recognition that comes with experience. ${ }^{3}$ Taking extra time on every exam is difficult; therefore, identification of APROP suspects is helpful. Red flags include: 1) annular, c-shaped, or arc-shaped hemorrhages that often arise adjacent to neovascularization and 2) retina vessels that lose detail or disappear as they approach the avascular retina. ${ }^{3}$

APROP is treated either by laser therapy or by antivascular endothelial growth factor (anti-VEGF) therapy. We aimed to investigate the postnatal characteristics of preterm neonates who developed APROP by comparing the clinical criteria of preterm neonates who developed APROP with those of gestational age (GA)- and birth weight (BW)-matched controls, who developed only mild ROP (no more than stage 2). We also compared the postnatal characteristics of patients with APROP who responded to the first treatment and those with APROP who needed retreatment in order to further analyze risk factors for "severe" APROP.

\section{Materials and Methods}

The current study included infants with APROP in zone 1 or posterior zone 2, born between January 1, 2018 and December 31, $2020(n=16)$. We performed a retrospective review of medical data from birth to discharge or mortality. Data on gestational age (GA) and birth weight (BW) were recorded, as well as data on neonatal morbidities; BPD, NEC, IVH, and sepsis. We recorded the laboratory results of the serum hemoglobin, hematocrit, platelet count and white blood cell count at the time of screening. We also recorded the lowest results of the serum hemoglobin and the platelet count. The serum C-reactive protein (CRP) value was recorded, as well as transfusion data (plasma, red blood cell and platelet transfusions) and data on inotropic support. The primary inotrope used in our unit is dopamine. We also recorded the neonatal outcome and the available data on maternal risk factors. We reviewed the records for data on ROP status, development, and treatment interventions. We recorded the postnatal age and postconceptional age (PCA) at which retinal findings were detected on screening.

Thirty-four BW (within 100g) and GA (within 1 week) matched controls who were admitted during the same period were also included. Controls were confirmed to have only mild ROP, no worse than ROP stage 2. For the controls, we retrospectively reviewed the medical records for data equivalent to those retrieved for the APROP cases, up to discharge.

\section{Clinical Risk Factors}

We used the National Institute of Child Health and Human Development definition of bronchopulmonary dysplasia (BPD). A positive blood culture was used to diagnose sepsis. If the results of blood culture were not available, sepsis was diagnosed by a positive C-reactive protein and immature-to-total neutrophil ratio of more than 0.2 in the presence of clinical manifestations of sepsis. Early-onset sepsis was defined as occurring in the first 3 postnatal days, while late-onset sepsis (LOS) was defined as occurring at $>72 \mathrm{~h}$ of life. The modified Bell staging criteria were used to define necrotizing enterocolitis. Cranial ultrasound was used to diagnose intraventricular hemorrhage. Small for GA (SGA) was defined as having a BW less than the 10th percentile for GA.

\section{Ethical Approval}

The study design conformed to the Revised Declaration of Helsinki and was approved by the Scientific Ethics Committee of the Pediatric Department of the Faculty of Medicine, Cairo University. Informed consent was obtained from the parents of the patients included in the study.

\section{Screening for ROP}

All the infants were screened at Cairo University Children Hospital using wide-field digital retinal imaging. Eye drops to dilate the pupils (Cyclophrine 1\%, Kahira Pharmaceuticals and Chemical Industries Company, Cairo, Egypt), which contain $0.2 \%$ cyclopentolate and $0.1 \%$ phenylephrine, were applied at least 30 minutes prior to examination. Topical anesthetic eye drops, benoxinate hydrochloride (Egyptian International Pharmaceuticals Industries Company, Cairo, Egypt), were instilled and an eyelid speculum was inserted. A clear topical lubricant gel was used during imaging (GenTeal gel, Excelvision AG Hettlingen, Zürich, Switzerland). Digital images were taken with the RetCam Shuttle Ophthalmic Imaging System (Clarity Medical Systems, Pleasanton, CA, USA) using the $130^{\circ}$ ROP lens. The Ret-Cam screening was performed by a trained neonatologist. A series of 1 to 10 fundus photos of the posterior pole, four quadrants, and periphery were taken for each infant. Infants were comforted by administering sucrose solution, swaddling, and nesting during 
screening. The images were stored on the hard drive of the Ret-Cam. We examined inpatients as well as patients who had been discharged and were coming for followup. If ROP was detected, a pediatric ophthalmologist trained in ROP screening confirmed the diagnosis, extent of ROP and the necessity of treatment using indirect ophthalmoscopy with a 28-D lens and scleral depression.

Preterm neonates were initially screened according to the schedule recommended by the American Academy of Pediatrics (AAP) statement on screening of preterm infants for ROP $2018,{ }^{6}$ or before discharge, whichever was earlier. Examinations were performed until complete retinal vascularization. Retinopathy of prematurity was classified according to the Revised International Classification of Retinopathy of Prematurity. ${ }^{1}$ The presence or absence of ROP and plus disease were recorded.

\section{Treatment of ROP}

Treatment of ROP was based on the Early Treatment for ROP (ETROP) guidelines. ${ }^{7}$ Patients diagnosed with aggressive posterior ROP were managed by intravitreal anti-vascular endothelial growth factor injection (antiVEGF) or indirect laser ablation. Patients were initially treated with intravitreal anti-VEGF therapy $(0.625 \mathrm{mg} /$ $0.025 \mathrm{cc}$ of Bevacizumab, Roche, US), and retreatment was done using another dose of anti-VEGF therapy or laser therapy. Laser was delivered via an LIO (Laser indirect ophthalmoscope) attached to the IRIDEX ${ }^{\circledR}$ infrared diode $(850 \mathrm{~nm})$ laser console (California, US).

\section{Statistical Analysis}

The statistical package SPSS version 20 was used for data entry, coding, and analysis (IBM Corp, Armonk, New York, United States). Descriptive data were presented as median and range for quantitative variables that were not normally distributed, and as number and percent for qualitative variables. Qualitative variables were compared between groups using the Chi-square test, but Fishers' Exact test was used when the expected frequency was less than five. Mann Whitney test was used to compare quantitative variables which were not normally distributed. $\mathrm{P}$-values $<0.05$ were considered significant.

\section{Results}

The birth characteristics of the 16 patients with APROP and their 34 matched controls are shown in Table 1. There was no statistically significant difference in the GA and the
BW of patients who had APROP and the controls who were matched regarding their GA and their BW.

The APGAR scores at 1 and 5 mins were not statistically different between patients who developed APROP and those who did not. Maternal risk factors such as maternal age, premature rupture of membranes (PROM), preeclampsia, maternal steroid use, and history of maternal illness did not differ significantly between APROP and non-APROP infants (Table 1).

The postnatal clinical course of the APROP cases and the controls are shown in Table 2. Patients who developed APROP were significantly more likely to be SGA than the controls. The duration of admission did not differ significantly between both groups $(\mathrm{p}=0.371$, Table 2$)$; however, the period of caffeine citrate treatment during hospital admission was significantly higher in the patients who had APROP compared to the controls ( $\mathrm{p}=0.037$, Table 2 ). The requirement of oxygen therapy, and the requirement of mechanical ventilation or CPAP were not statistically different between both groups. The total duration of oxygen therapy, and the duration of ventilation also did not differ significantly between patients who developed APROP and patients who did not develop APROP. There was no difference in the incidence of EOS or LOS between both groups. However, significantly more patients with APROP had a positive blood culture compared to patients without APROP ( $\mathrm{p}=0.043$, Table 2). The incidence of other neonatal complications during the hospital stay (NEC, BPD, pneumothorax, IVH) did not differ between both groups of patients (Table 2).

The blood picture parameters ( $\mathrm{Hb}$ at screening, WBC count at screening, platelet count at screening, lowest $\mathrm{Hb}$, and lowest platelet count), and the sepsis marker CRP did not differ between patients with APROP and patients without APROP (Table 2). Transfusion of packed RBCs did not differ significantly between both groups. There was also no difference in the requirement of platelet transfusions between both groups (Table 2).

The postnatal age (PNA) at which findings were detected during screening was significantly lower in patients with APROP compared to patients without APROP ( $p=0.025$, Table 2). However, there was no statistically significant difference in the postconceptional age at which findings were detected on screening between patients with APROP compared to the controls $(\mathrm{p}=0.817$, Table 2). All the patients who developed APROP had plus disease, compared to none of the controls who had stage 2 or less ROP and no Plus ( $<<0.001$, Table 2). Figure 1 
Table I Comparison of the Birth Characteristics of the Study Groups

\begin{tabular}{|c|c|c|c|}
\hline Variable & $\begin{array}{l}\text { APROP } \\
(n=16)\end{array}$ & $\begin{array}{c}\text { No APROP } \\
(n=34)\end{array}$ & $P$ value \\
\hline $\begin{array}{l}\text { GA, wks, median } \\
\text { (range) }\end{array}$ & $\begin{array}{c}31.5 \\
(27-34)\end{array}$ & $31(28-33)$ & 0.447 \\
\hline BW, g, median (range) & $\begin{array}{c}1175 \\
(940-1520)\end{array}$ & $\begin{array}{c}1280 \\
(890-1580)\end{array}$ & 0.148 \\
\hline $\begin{array}{l}\text { Gender, n (\%) } \\
\text { Male } \\
\text { Female }\end{array}$ & $\begin{array}{l}9 \\
7\end{array}$ & $\begin{array}{l}16 \\
18\end{array}$ & 0.544 \\
\hline $\begin{array}{l}\text { Maternal age, yr, median } \\
\text { (range) }\end{array}$ & $28(18-42)$ & $27(17-37)$ & 0.942 \\
\hline $\begin{array}{l}\text { Mode of delivery, n (\%) } \\
\text { Yes } \\
\text { No }\end{array}$ & $\begin{array}{l}14 \\
2\end{array}$ & $\begin{array}{l}24 \\
10\end{array}$ & 0.292 \\
\hline $\begin{array}{l}\text { RDS, n (\%) } \\
\text { Yes } \\
\text { No }\end{array}$ & $\begin{array}{c}15 \\
1\end{array}$ & $\begin{array}{c}33 \\
1\end{array}$ & $0.542^{\wedge}$ \\
\hline $\begin{array}{l}\text { Surfactant, n (\%) } \\
\text { Yes } \\
\text { No }\end{array}$ & $\begin{array}{c}6 \\
10\end{array}$ & $\begin{array}{l}14 \\
20\end{array}$ & 0.804 \\
\hline $\begin{array}{l}\text { History of PROM, n (\%) } \\
\text { Yes } \\
\text { No }\end{array}$ & $\begin{array}{c}6 \\
10\end{array}$ & $\begin{array}{c}7 \\
27\end{array}$ & $0.301^{\wedge}$ \\
\hline $\begin{array}{l}\text { Antenatal steroid use, } \\
\text { n (\%) } \\
\text { Yes } \\
\text { No }\end{array}$ & $\begin{array}{l}9 \\
7\end{array}$ & $\begin{array}{l}10 \\
24\end{array}$ & 0.068 \\
\hline $\begin{array}{l}\text { History of maternal } \\
\text { illness, n (\%) } \\
\text { Yes } \\
\text { No }\end{array}$ & $\begin{array}{l}8 \\
8\end{array}$ & $\begin{array}{c}9 \\
25\end{array}$ & 0.101 \\
\hline
\end{tabular}

Note: ^Fisher's exact test.

shows the retinal image of one of the patients which was included in the study showing early APROP (pre-APROP) with an immature retina in zone 1 in some areas and subtle changes in the vascular-avascular junction with a small annular hemorrhage (Figure 1A). Figure 1B shows the retinal image of the same patient after development of clear APROP, with plus disease and hemorrhages in zone 1. The retinal images of the 16 patients with APROP are shown in Figure 2.

All the patients with APROP received treatment with anti-VEGF therapy but 6 of them subsequently required retreatment (one was retreated with anti-VEGF therapy and 5 were retreated with laser therapy). The outcome was favorable in 15/16 of the patients who suffered from APROP. One patient had a favorable prognosis in one eye but progression to partial retinal detachment in the other eye after having received bilateral anti-VEGF therapy. We compared the patients with APROP who required retreatment $(n=6)$ to the patients with APROP who did not require retreatment $(n=10)$.

Patients with APROP who required retreatment had received inotropes for a significantly longer duration of time and had received plasma transfusions more frequently than patients who did not require retreatment $(\mathrm{p}=0.007$, $\mathrm{p}=0.040$, respectively, Table 3 ). Patients with APROP who needed retreatment were also significantly more likely to have intraventricular hemorrhage (4/6) than patients with APROP who did not need retreatment $(1 / 10) \quad(p=0.036$, Table 3). The lowest serum hemoglobin during admission was significantly lower among patients with APROP who needed retreatment compared to the patients with APROP who did not need retreatment $(\mathrm{p}=0.028$, Table 3 ).

\section{Discussion}

We aimed to analyze the risk factors and clinical features of patients who developed APROP in comparison to patients who developed non-treatment requiring ROP. In this retrospective 1:2 case control study we found that being born SGA, the duration of caffeine citrate treatment, and having a positive blood culture were significantly associated with the development of APROP.

The duration of caffeine citrate treatment differed significantly between patients with APROP and those with stage 2 or less ROP. This agrees with a previous study which studied the association of caffeine citrate with the occurrence and severity of retinopathy of prematurity (ROP) and found that the total dose of caffeine was significantly associated with the development of any ROP ( $p$ $=0.003 ; \mathrm{RR}=1.03[95 \% \mathrm{CI}, 1.01-1.05])$ and the need for treatment $(\mathrm{p}=0.006, \mathrm{RR}=1.073[95 \% \mathrm{CI} ; 1.021-1.13]){ }^{8}$

Studies are conflicting regarding the side effects of caffeine citrate therapy. In the CAP trial, ROP detection rates did not differ significantly between both groups; ${ }^{9}$ however, fewer infants in the caffeine group demonstrated severe ROP compared to the control group (5.1\% vs $7.9 \%$; adjusted OR: $0.61,95 \% \mathrm{CI}: 0.42-0.89) .{ }^{10}$

The mechanism of action of methylxanthines is through non-specific inhibition of $\mathrm{A} 1$ and $\mathrm{A} 2 \mathrm{a}$ adenosine 
Table 2 Comparison of the Postnatal Characteristics of the Study Groups

\begin{tabular}{|c|c|c|c|}
\hline Variable & APROP $(n=16)$ & No APROP $(n=34)$ & $\mathbf{P}$ value \\
\hline Duration of admission, days, median (range) & $47.5(23-154)$ & $4 \mid(18-143)$ & 0.371 \\
\hline Days of caffeine treatment, median (range) & $40.5(18-90)$ & $27.5(17-87)$ & $0.037^{*}$ \\
\hline Start of enteral feeding, days, median (range) & $2(2-17)$ & $2(2-10)$ & 0.561 \\
\hline TPN duration, days, median (range) & $22(6-53)$ & $16.5(7-5 \mid)$ & 0.362 \\
\hline Oxygen therapy, n (\%) & & & 0.542 \\
\hline Yes & 15 & 33 & \\
\hline No & 1 & 1 & \\
\hline Duration of oxygen therapy, days, median (range) & $29(11-110)$ & $30(5-143)$ & 1.000 \\
\hline MV, n (\%) & & & 0.680 \\
\hline Yes & 7 & 17 & \\
\hline No & 9 & 17 & \\
\hline MV Duration, days, median (range) & $9(2-47)$ & $20(2-97)$ & 0.318 \\
\hline CPAP, n (\%) & & & $0.650^{\wedge}$ \\
\hline Yes & 14 & 31 & \\
\hline No & 2 & 3 & \\
\hline CPAP Duration, days, median (range) & $12(3-43)$ & $8(I-47)$ & 0.197 \\
\hline Blender oxygen, n (\%) & & & $1.000^{\wedge}$ \\
\hline Yes & 14 & 30 & \\
\hline No & 2 & 4 & \\
\hline Blender Duration, days, median (range) & $6(3-14)$ & $6(1-16)$ & 1.000 \\
\hline Headbox, n (\%) & & & 0.468 \\
\hline Yes & 14 & 26 & \\
\hline No & 2 & 8 & \\
\hline Headbox Duration, days, median (range) & $2(1-9)$ & $2(1-6)$ & 0.492 \\
\hline Incubator oxygen, n (\%) & & & 1.000 \\
\hline Yes & 14 & 28 & \\
\hline No & 2 & 6 & \\
\hline Incubator oxygen duration, days, median (range) & $2.5(1-12)$ & $3(1-8)$ & 0.967 \\
\hline BPD, n (\%) & & & 1.000 \\
\hline Yes & 8 & 17 & \\
\hline No & 8 & 17 & \\
\hline Pneumothorax, n (\%) & & & 0.699 \\
\hline Yes & 2 & 7 & \\
\hline No & 14 & 27 & \\
\hline NEC, n (\%) & & & 0.434 \\
\hline Yes & 7 & 11 & \\
\hline No & 9 & 23 & \\
\hline EOS, n (\%) & & & 0.151 \\
\hline Yes & 11 & 16 & \\
\hline No & 5 & 18 & \\
\hline
\end{tabular}


Table 2 (Continued).

\begin{tabular}{|c|c|c|c|}
\hline Variable & APROP $(n=16)$ & No APROP $(n=34)$ & $P$ value \\
\hline LOS, n (\%) & & & 1.000 \\
\hline Yes & 16 & 32 & \\
\hline No & 0 & 2 & \\
\hline Positive culture, n (\%) & & & $0.043^{*}$ \\
\hline Yes & 14 & 20 & \\
\hline No & 2 & 14 & \\
\hline Jaundice, n (\%) & & & 0.746 \\
\hline Yes & II & 25 & \\
\hline No & 5 & 9 & \\
\hline PDA, n (\%) & & & 0.846 \\
\hline Yes & 8 & 16 & \\
\hline No & 8 & 18 & \\
\hline Inotropes, n (\%) & & & $0.746^{\wedge}$ \\
\hline Yes & 11 & 25 & \\
\hline No & 5 & 9 & \\
\hline Duration of inotropes days, median (range) & $13(7-37)$ & $12(2-34)$ & 0.710 \\
\hline Packed RBC transfusion, $\mathrm{n}(\%)$ & & & 0.880 \\
\hline Yes & 10 & 22 & \\
\hline No & 6 & 12 & \\
\hline Number of RBC transfusions, median (range) & $2(0-12)$ & I $(0-7)$ & 0.599 \\
\hline Plasma transfusions, n (\%) & & & 0.224 \\
\hline Yes & 9 & 14 & \\
\hline No & 6 & 20 & \\
\hline Number of plasma transfusions, median (range) & $3(0-17)$ & I (0-14) & 0.859 \\
\hline Thrombocytopenia, $\mathrm{n}(\%)$ & & & 0.464 \\
\hline Yes & 13 & 25 & \\
\hline No & 2 & 9 & \\
\hline Platelet transfusion, $\mathrm{n}(\%)$ & & & $1.000^{\wedge}$ \\
\hline Yes & 3 & 6 & \\
\hline No & 13 & 28 & \\
\hline $\mathrm{IVH}, \mathrm{n}(\%)$ & & & 0.386 \\
\hline Yes & 5 & 15 & \\
\hline No & 11 & 19 & \\
\hline IVH Grade, median (range) & $3(3-4)$ & $2(1-4)$ & 0.804 \\
\hline Inhaled steroids, n (\%) & & & 0.370 \\
\hline Yes & 13 & 31 & \\
\hline No & 3 & 3 & \\
\hline Duration of inhaled steroids days, median (range) & $18(0-59)$ & $15.5(0-87)$ & 0.747 \\
\hline SGA, n (\%) & & & $0.002 *$ \\
\hline Yes & 10 & 6 & \\
\hline No & 6 & 28 & \\
\hline
\end{tabular}

(Continued) 
Table 2 (Continued).

\begin{tabular}{|c|c|c|c|}
\hline Variable & $\operatorname{APROP}(n=16)$ & No APROP $(n=34)$ & $P$ value \\
\hline Multiple gestation, n (\%) & & & 0.157 \\
\hline Yes & 8 & 10 & \\
\hline No & 8 & 24 & \\
\hline $\mathrm{Hb}$ at screening, $\mathrm{g} / \mathrm{dL}$, median (range) & $10.5(6-15)$ & $8.5(6-14)$ & 0.297 \\
\hline WBC count at screening, $\times 10^{9} / \mathrm{L}$, median (range) & $12.45(5-24.8)$ & $10.5(1.6-42)$ & 0.231 \\
\hline Platelet count at screening, $\times 10^{9} / \mathrm{L}$, median (range) & $222(33-683)$ & $205(28-643)$ & 0.948 \\
\hline Lowest $\mathrm{Hb}, \mathrm{g} / \mathrm{dL}$, median (range) & $7.6(5-13)$ & $8(6-13)$ & 0.584 \\
\hline Lowest platelet count, $\times 10^{9} / \mathrm{L}$, median (range) & $88(11-222)$ & $89.5(|2-4| 2)$ & 0.410 \\
\hline Serum albumin & $3(2-4)$ & $2.9(2-4)$ & 0.641 \\
\hline Positive CRP, n (\%) & & & 1.000 \\
\hline Yes & 11 & 26 & \\
\hline No & 4 & 8 & \\
\hline Age at screening findings, days, median (range) & $22.5(\mid 7-31)$ & $26(17-42)$ & $0.025 *$ \\
\hline PCA at screening findings, weeks, median (range) & $34(3 I-36.4)$ & $35(31-38)$ & 0.817 \\
\hline Plus disease, $\mathrm{n}(\%)$ & & & $<0.0001$ \\
\hline Yes & 16 & 0 & \\
\hline No & 0 & 34 & \\
\hline Intervention, n (\%) & & & $<0.0001$ \\
\hline Yes & 16 & 0 & \\
\hline No & 0 & 34 & \\
\hline Outcome, n (\%) & & & $0.409^{\wedge}$ \\
\hline Discharge & 15 & 27 & \\
\hline Mortality & I & 7 & \\
\hline
\end{tabular}

Notes: $* \mathrm{P}<0.05$ considered significant. ^Fisher's exact test.

receptors, and therefore they attenuate adenosine induced vasodilation that can potentially impair cerebral blood flow. ${ }^{11}$ In previous reports, a loading dose of caffeine citrate in preterm infants was associated with a significant reduction of cerebral blood flow. ${ }^{12,13}$ In addition, elimination of caffeine is slower in the preterm and term neonate, compared with older children and adults, as a result of immaturity of hepatic enzymes and immaturity of renal functions. ${ }^{14}$

Studies suggest a similar effect of caffeine on the retinal blood vessels. ${ }^{15,16}$ Whether caffeine has a similar effect on the retinal blood vessels of preterm neonates especially if a longer duration and therefore larger cumulative doses of caffeine are used still needs to be proven. Our results suggest that a longer duration of caffeine citrate therapy is a risk factor for APROP.
Being SGA, defined as a BW less than the 10th percentile for GA, was another significant risk factor for APROP in our study. It has been well documented that babies born SGA have an increased risk of developing severe ROP. ${ }^{17,18}$ Chronic uterine hypoxia, abnormal growth factor levels, antioxidant deficiency, and free oxygen radicals in utero have been implicated as being responsible factors for the increased risk of severe ROP and the rapidity of its development in SGA babies. ${ }^{19}$ Growth-restricted babies have reduced serum IGF-1 levels in utero, which are known to increase the risk and severity of ROP. Therefore, if these babies are born prematurely, they develop severe ROP earlier than non-growthrestricted babies of a similar $\mathrm{GA}^{20}$

In a recent study, infants who developed APROP were more likely to be small for their GA compared to non-APROP 

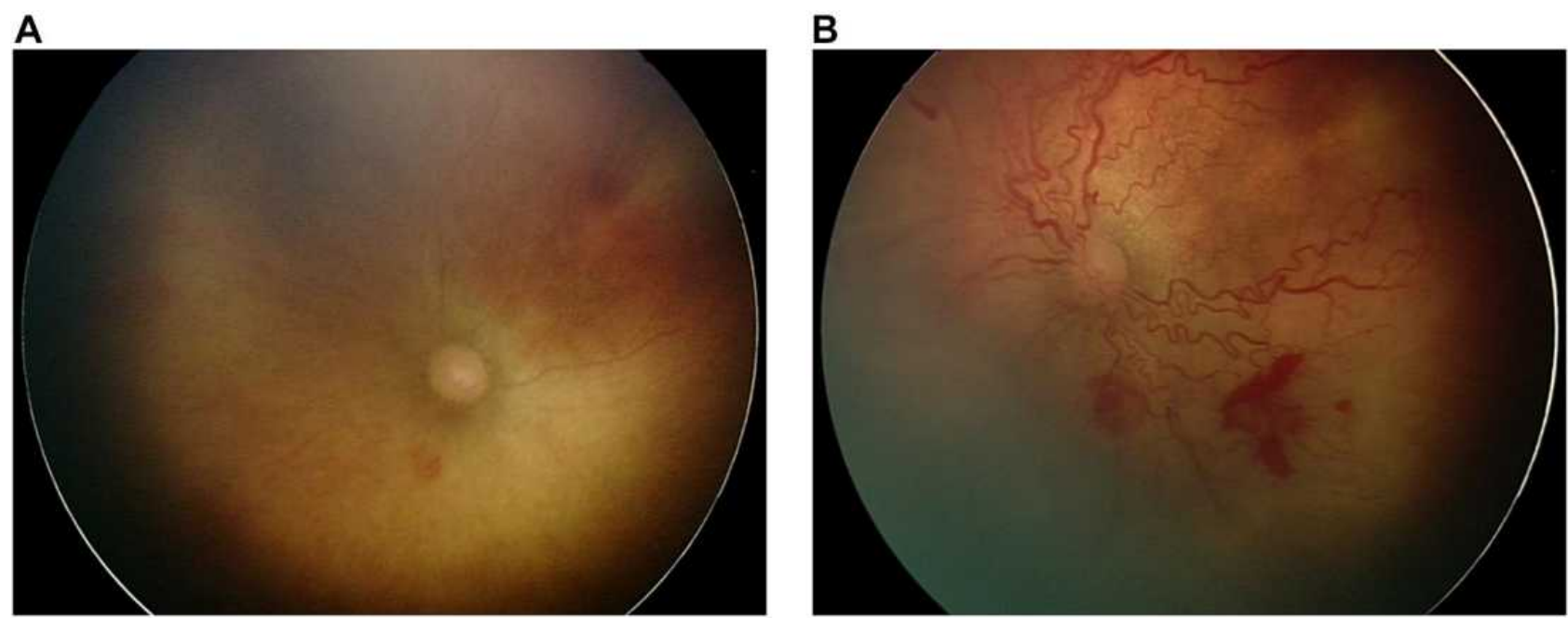

Figure I (A) Pre-APROP (early APROP) areas of avascular retina in zone I and subtle changes at the vascular-avascular junction with a small annular hemorrhage. (B) Rapid progression to APROP with plus disease and hemorrhages.

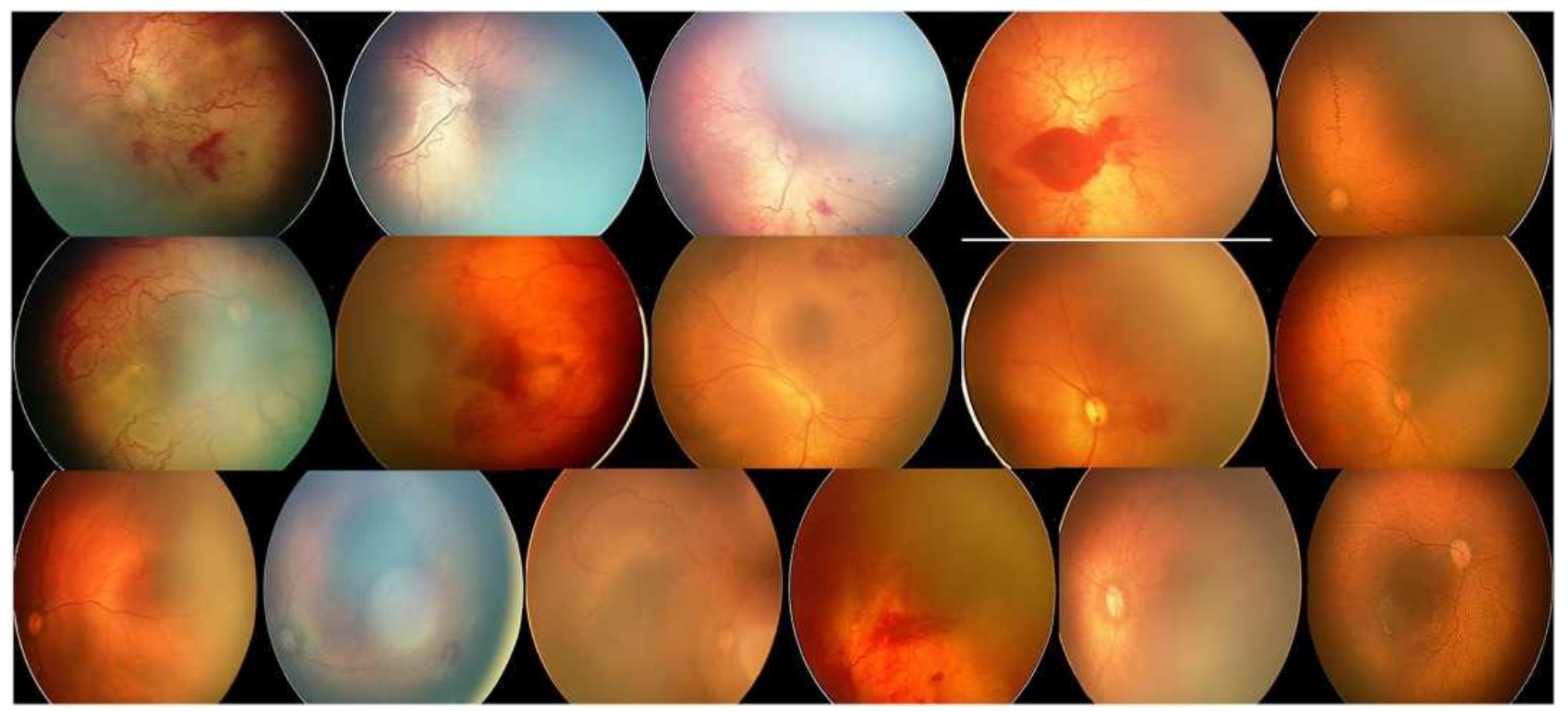

Figure 2 Retinal images of the patients with APROP.

patients $(\mathrm{p}<0.001){ }^{21}$ Misra et al, 2008 reported that prethreshold type 1 ROP can occur before 6-7 weeks postnatal age especially in SGA babies and therefore recommended earlier screening starting at 4 weeks PNA for SGA babies. ${ }^{20}$

Neonatal sepsis has been identified as a risk factor for ROP and severe ROP in previous studies. ${ }^{22-24}$ Patients with APROP in our study were more likely to have a positive blood culture during hospital admission than patients without APROP.

In our study, findings on retinal examinations were discovered at an earlier postnatal age in patients who developed APROP compared to patients who did not develop APROP ( $p=0.025$, Table 2 ). However, the postconceptional age at the time of retinal findings was similar in both groups $(p=0.817$, Table 2$)$. These findings agree with previous studies that state that the time of occurrence of ROP correlates better with postconceptional age rather than postnatal age. ${ }^{25,26}$

APROP regressed in 31/32 eyes of 16 patients following treatment. Intravitreal bevacizumab injection was performed as the primary treatment in our study. One patient had a favorable outcome in one eye but progression to 
Table 3 Comparison of the Prenatal and Postnatal Characteristics of Neonates with APROP Who Did Not Need Retreatment ( $\mathrm{n}=10)$ and Those Who Required Retreatment $(n=6)$

\begin{tabular}{|c|c|c|c|}
\hline Variable & $\begin{array}{c}\text { Patients with APROP Who Did Not Need } \\
\text { Retreatment }(n=10)\end{array}$ & $\begin{array}{l}\text { Patients with APROP Who Needed } \\
\text { Retreatment }(n=6)\end{array}$ & $\mathbf{P}$ value \\
\hline GA, wks, median (range) & $31.5(28-33)$ & $31.5(27-34)$ & 0.958 \\
\hline BW, g, median (range) & $1175(1030-1340)$ & $1125(940-1520)$ & 0.875 \\
\hline Gender, n (\%) & & & 1.000 \\
\hline Male & 6 & 3 & \\
\hline Female & 4 & 3 & \\
\hline Maternal age, yrs, median (range) & $29.5(19-42)$ & $23(18-34)$ & 0.313 \\
\hline CS delivery, n (\%) & & & $1.000^{\wedge}$ \\
\hline Yes & 9 & 5 & \\
\hline No & 1 & 1 & \\
\hline RDS, n (\%) & & & $1.000^{\wedge}$ \\
\hline Yes & 9 & 6 & \\
\hline No & 1 & 0 & \\
\hline Survanta, n (\%) & & & $0.607^{\wedge}$ \\
\hline Yes & 3 & 3 & \\
\hline No & 7 & 3 & \\
\hline History of PROM, n (\%) & & & $1.000^{\wedge}$ \\
\hline Yes & 4 & 2 & \\
\hline No & 6 & 4 & \\
\hline Multiple gestation, n (\%) & & & $0.608^{\wedge}$ \\
\hline Yes & 4 & 4 & \\
\hline No & 6 & 2 & \\
\hline $\begin{array}{l}\text { Number of multiple gestations, } \\
\text { median (range) }\end{array}$ & $0(0-3)$ & $I(0-I)$ & 0.875 \\
\hline $\begin{array}{l}\text { Duration of admission, days, median } \\
\text { (range) }\end{array}$ & $41.5(28-87)$ & $54(23-154)$ & 0.313 \\
\hline $\begin{array}{l}\text { Days of caffeine treatment, median } \\
\text { (range) }\end{array}$ & $39(|8-8|)$ & $44(23-90)$ & 0.428 \\
\hline $\begin{array}{l}\text { Start of enteral feeding, days, median } \\
\text { (range) }\end{array}$ & $2(2-17)$ & $2(2-5)$ & 0.958 \\
\hline TPN duration, days, median (range) & $19(6-43)$ & $47(12-53)$ & 0.129 \\
\hline Oxygen therapy, n (\%) & & & $1.000^{\wedge}$ \\
\hline Yes & 9 & 6 & \\
\hline No & 1 & 0 & \\
\hline $\begin{array}{l}\text { Duration of oxygen therapy, days, } \\
\text { median (range) }\end{array}$ & $26(0-33)$ & $33(17-110)$ & 0.492 \\
\hline MV, n (\%) & & & $0.302^{\wedge}$ \\
\hline Yes & 3 & 4 & \\
\hline No & 7 & 2 & \\
\hline MV duration, days, median (range) & $0(0-18)$ & $5.5(0-47)$ & 0.181 \\
\hline
\end{tabular}


Table 3 (Continued).

\begin{tabular}{|c|c|c|c|}
\hline Variable & $\begin{array}{c}\text { Patients with APROP Who Did Not Need } \\
\text { Retreatment }(n=10)\end{array}$ & $\begin{array}{c}\text { Patients with APROP Who Needed } \\
\text { Retreatment }(n=6)\end{array}$ & $P$ value \\
\hline CPAP, n (\%) & & & $1.000^{\wedge}$ \\
\hline Yes & 9 & 5 & \\
\hline No & 1 & I & \\
\hline CPAP duration, days, median (range) & $12(0-22)$ & $7.5(0-43)$ & 0.713 \\
\hline Blender oxygen, $\mathrm{n}(\%)$ & & & $1.000^{\wedge}$ \\
\hline Yes & 9 & 5 & \\
\hline No & 1 & I & \\
\hline $\begin{array}{l}\text { Blender duration, days, median } \\
\text { (range) }\end{array}$ & $5.5(0-8)$ & $6(0-14)$ & 0.492 \\
\hline Headbox, n (\%) & & & $1.000^{\wedge}$ \\
\hline Yes & 9 & 5 & \\
\hline No & 1 & 1 & \\
\hline $\begin{array}{l}\text { Headbox duration, days, median } \\
\text { (range) }\end{array}$ & $2.5(0-4)$ & $1.5(0-9)$ & 0.313 \\
\hline Incubator oxygen, n (\%) & & & $1.000^{\wedge}$ \\
\hline Yes & 9 & 5 & \\
\hline No & I & 1 & \\
\hline $\begin{array}{l}\text { Incubator oxygen duration, days, } \\
\text { median (range) }\end{array}$ & $2(0-4)$ & $3.5(0-12)$ & 0.073 \\
\hline BPD, n (\%) & & & $1.000^{\wedge}$ \\
\hline Yes & 5 & 3 & \\
\hline No & 5 & 3 & \\
\hline Pneumothorax, n (\%) & & & 0.125 \\
\hline Yes & 0 & 2 & \\
\hline No & 10 & 4 & \\
\hline NEC, n (\%) & & & $1.000^{\wedge}$ \\
\hline Yes & 4 & 3 & \\
\hline No & 6 & 3 & \\
\hline EOS, n (\%) & & & $0.093^{\wedge}$ \\
\hline Yes & 5 & 6 & \\
\hline No & 5 & 0 & \\
\hline LOS, n (\%) & & & - \\
\hline Yes & 10 & 6 & \\
\hline No & 0 & 0 & \\
\hline Positive CRP, n (\%) & & & $1.000^{\wedge}$ \\
\hline Yes & 7 & 4 & \\
\hline No & 3 & 1 & \\
\hline Culture proven sepsis, n (\%) & & & $0.500^{\wedge}$ \\
\hline Yes & 8 & 6 & \\
\hline No & 2 & 0 & \\
\hline
\end{tabular}

(Continued) 
Table 3 (Continued).

\begin{tabular}{|c|c|c|c|}
\hline Variable & $\begin{array}{c}\text { Patients with APROP Who Did Not Need } \\
\text { Retreatment }(n=10)\end{array}$ & $\begin{array}{c}\text { Patients with APROP Who Needed } \\
\text { Retreatment }(n=6)\end{array}$ & $P$ value \\
\hline Jaundice, n (\%) & & & $0.588^{\wedge}$ \\
\hline Yes & 6 & 5 & \\
\hline No & 4 & 1 & \\
\hline PDA, n (\%) & & & $0.608^{\wedge}$ \\
\hline Yes & 6 & 2 & \\
\hline No & 4 & 4 & \\
\hline Inotropes, n (\%) & & & $0.093^{\wedge}$ \\
\hline Yes & 5 & 6 & \\
\hline No & 5 & 0 & \\
\hline $\begin{array}{l}\text { Duration of inotropes, days, median } \\
\text { (range) }\end{array}$ & $3.5(0-14)$ & $18.5(11-37)$ & $0.007^{*}$ \\
\hline Packed RBC transfusion, $\mathrm{n}(\%)$ & & & $0.307^{\wedge}$ \\
\hline Yes & 5 & 5 & \\
\hline No & 5 & I & \\
\hline $\begin{array}{l}\text { Number of RBC transfusions, median } \\
\text { (range) }\end{array}$ & $2(0-5)$ & $4(0-12)$ & 0.263 \\
\hline Plasma transfusions, $\mathrm{n}(\%)$ & & & $0.580^{\wedge}$ \\
\hline Yes & 5 & 4 & \\
\hline No & 5 & I & \\
\hline $\begin{array}{l}\text { Number of plasma transfusions, } \\
\text { median (range) }\end{array}$ & $2(0-6)$ & $7(3-17)$ & $0.040^{*}$ \\
\hline Thrombocytopenia, n (\%) & & & $0.524^{\wedge}$ \\
\hline Yes & 8 & 5 & \\
\hline No & 2 & 0 & \\
\hline Platelet transfusion, $\mathrm{n}(\%)$ & & & $0.518^{\wedge}$ \\
\hline Yes & 1 & 2 & \\
\hline No & 9 & 4 & \\
\hline $\mathrm{IVH}, \mathrm{n}(\%)$ & & & $0.036 *$ \\
\hline Yes & 1 & 4 & \\
\hline No & 9 & 2 & \\
\hline IVH Grade, median (range) & $0(0-3)$ & $3(0-4)$ & 0.056 \\
\hline Inhaled steroids, $\mathrm{n}(\%)$ & & & $1.000^{\wedge}$ \\
\hline Yes & 8 & 5 & \\
\hline No & 2 & I & \\
\hline $\begin{array}{l}\text { Duration of inhaled steroids, days, } \\
\text { median (range) }\end{array}$ & $17.5(0-38)$ & $32.5(0-59)$ & 0.368 \\
\hline SGA, n (\%) & & & $0.607^{\wedge}$ \\
\hline Yes & 7 & 3 & \\
\hline No & 3 & 3 & \\
\hline $\begin{array}{l}\text { Postnatal age at screening findings, } \\
\text { days, median (range) }\end{array}$ & $22(17-29)$ & $23(|7-3|)$ & 0.699 \\
\hline
\end{tabular}


Table 3 (Continued).

\begin{tabular}{|c|c|c|c|}
\hline Variable & $\begin{array}{c}\text { Patients with APROP Who Did Not Need } \\
\text { Retreatment }(n=10)\end{array}$ & $\begin{array}{c}\text { Patients with APROP Who Needed } \\
\text { Retreatment }(n=6)\end{array}$ & $P$ value \\
\hline $\begin{array}{l}\text { PCA at screening findings, weeks, } \\
\text { median (range) }\end{array}$ & $34(3 \mid-36)$ & $36(33-36.4)$ & 0.298 \\
\hline $\mathrm{Hb}$ at screening, $\mathrm{g} / \mathrm{dL}$, median (range) & II (7-15) & $9.5(6-13)$ & 0.368 \\
\hline $\begin{array}{l}\text { WBC count at screening, count } \times 10^{9} / \\
L, \text { median (range) }\end{array}$ & $15(8.1-24.8)$ & $12(5-20)$ & 0.635 \\
\hline $\begin{array}{l}\text { Platelet count at screening, } \\
\text { count } \times 10^{9} / \mathrm{L} \text {, median (range) }\end{array}$ & $205(33-683)$ & $242(47-462)$ & 1.000 \\
\hline Lowest $\mathrm{Hb}, \mathrm{g} / \mathrm{dL}$, median (range) & $8(7-13)$ & $6(5-10)$ & $0.028^{*}$ \\
\hline Lowest platelet count, count $\times 10^{9} / \mathrm{L}$ & $90(18-222)$ & $67(|1-1| 4)$ & 0.310 \\
\hline Serum albumin, $\mathrm{g} / \mathrm{dL}$, median (range) & $3.15(0-4)$ & $2.7(3-3)$ & 0.254 \\
\hline Outcome, n (\%) & & & 0.375 \\
\hline Discharge & 10 & 5 & \\
\hline Mortality & 0 & I & \\
\hline
\end{tabular}

Notes: $* \mathrm{P}<0.05$ considered significant. ^Fisher's exact test.

partial retinal detachment in the other eye after the first intravitreal anti-VEGF injection. Six patients required retreatment. One patient was retreated with a second intravitreal bevacizumab injection in both eyes and 5 patients required bilateral laser therapy. These results are comparable to those of Sahinoglu-Keskek et al (2019) who reported a favorable outcome in all eyes $(n=15)$ with APROP. Intravitreal ranibizumab was used for primary treatment in their study; two eyes in their study needed a second intravitreal ranibizumab injection, and they used laser photocoagulation for recurrence. ${ }^{27}$

Comparison of the patients with APROP who needed retreatment (6/16) with those who did not need retreatment $(10 / 16)$ revealed that patients with APROP who needed retreatment had received inotropes for a longer duration of time, and had more frequent plasma transfusions $(\mathrm{p}=0.007$, $\mathrm{p}=0.040$, respectively, Table 3 ). These findings indicate that patients with APROP who needed retreatment had required support of their systemic circulation with the use of inotropes and colloids.

In previous studies, hypotension has been recognized as a predictor of severe ROP. ${ }^{28,29}$ The use of inotropes has also been previously identified as a risk factor for the occurrence of ROP. ${ }^{29}$ Hussein et al $2014^{8}$ found that the number of dopamine doses was significantly associated with the development of any ROP $(\mathrm{p}<0.001 ; \mathrm{RR}=1.07$ [95\% CI, 1.03-1.1]), the severity of ROP $(p<0.001$; RR $=$ 1.09 [95\% CI, 1.05-1.14]), and the need for treatment ( $\mathrm{p}<$ $0.001 ; \mathrm{RR}=1.09$ [95\% CI, 1.05-1.14]).

Mizoguchi et al (1999) reported that dopamine use in low birth weight neonates may be a risk factor for the development of threshold ROP and recommended more vigilant screening of high-risk neonates requiring dopamine therapy for systemic hypotension. ${ }^{29}$ It was previously hypothesized that a synergistic effect of hypoxia and dopamine might induce retinal vascular constriction in early neonatal life. ${ }^{29-31}$ More recently, Allegaert et al $(2004)^{32}$ also found an association between dopamine and grade 3 ROP, but it was no longer an independent risk factor in their study after correcting for either the CRIB score or oxygenation index in a multiple regression model; therefore, the authors concluded that dopamine is likely an indicator of cardiovascular instability and not an etiological factor in the pathogenesis of ROP. ${ }^{32}$ Patients who had APROP that required retreatment had received a longer duration of inotropic support in our study; therefore, we recommend careful screening of neonates who require inotropic support as it may be an indicator of susceptibility to developing APROP that may require retreatment. 
Several studies reported a significant association between anemia and ROP, but other studies found that anemia was not an independent risk factor. ${ }^{33}$ In our study, the serum hemoglobin at the time of screening and the lowest hemoglobin during hospital admission did not differ significantly between patients with APROP and patients without APROP. However, the lowest hemoglobin during the hospital stay was significantly less in patients with APROP who needed retreatment compared to those who did not need retreatment $(\mathrm{p}=0.028$, Table 3$)$. Patients with APROP who needed retreatment were also more likely to suffer from intraventricular hemorrhage than those who did not need retreatment $(\mathrm{p}=0.036$, Table 3$)$. Intraventricular hemorrhage has been associated with ROP and severe ROP in previous studies. ${ }^{34-36}$

An association between thrombocytopenia and APROP has been previously reported, ${ }^{33,37}$ but we found no statistically significant difference in either the platelet count at the time of screening or the lowest platelet count during admission between patients with APROP and patients without APROP.

Since GA and BW and exposure to intrauterine adverse factors are predetermined at birth, therefore identification of modifiable postnatal factors that affect retinopathy of prematurity and especially APROP is important to minimize postnatal exposure to risk factors, and to be observant for early signs of possible progression to APROP in patients with these risk factors in order to allow earlier treatment.

In our study, patients who developed APROP had a significantly longer duration of caffeine therapy, were significantly more likely to be SGA and were more likely to have a positive blood culture than patients who developed less severe, non-treatment requiring ROP. Results of studies on caffeine use and development of ROP have differed. Differences may be explained by different caffeine doses, different population characteristics, or lack of adjustment for confounding variables. In our study there was a positive association between the duration of caffeine therapy and the development of APROP.

A closer look at the patients who developed APROP revealed that patients who required retreatment had received a longer duration of inotropes, had received a larger number of plasma transfusions, and were more likely to have IVH and a greater fall in the serum hemoglobin during hospitalization than patients whose ROP regressed after treatment only once with anti-VEGF therapy. These factors suggest that a more critical clinical course during hospitalization with the requirement of circulatory support predisposes preterm neonates to APROP that may require retreatment.

Limitations of our study include its retrospective design and the small number of patients. However, APROP, the severest form of ROP, is much less common than nontreatment requiring ROP. Larger studies that include a larger number of patients from multiple centers are needed to confirm these results. Increased vigilance and earlier screening of preterm neonates who were born SGA, or who received long durations of caffeine, or had sepsis or required circulatory support are essential for early detection of APROP in order to prevent unfavorable visual outcomes.

\section{Acknowledgments}

We thank Dr. Ahmed R Awadein MD, Dr. Ahmed M ElShewy MD, Dr. Heldz Khalil MSc, Dr. Mohammad Ashraf Bakr MSc, Dr. Nooran M Abdelkader MSc, who are eminent members of Cairo University's ROP screening team, for their enormous effort in the examination and treatment of patients and follow up of patients after treatment.

\section{Funding}

There is no funding source.

\section{Disclosure}

The authors declare that they have no conflict of interest.

\section{References}

1. International Committee for the Classification of Retinopathy of Prematurity. The international classification of retinopathy of prematurity revisited. Arch Ophthalmol. 2005;123(7):991-999. doi:10.1001/ archopht.123.7.991

2. Holmstrom G, Broberger U, Thomassen P. Neonatal risk factors for retinopathy of prematurity- a population-based study. Acta Ophthalmol Scand. 1998;76(2):204-207. doi:10.1034/j.16000420.1998.760216.x

3. Shapiro M, Blair M, Gonzalez J. Aggressive posterior retinopathy of prematurity (APROP). In: Andrés Kychenthal B, Paola Dorta S, editors. Retinopathy of Prematurity. Cham: Springer International Publishing AG; 2017:49-70.

4. Gole G, Ells A, Katz X, et al. The international classification of retinopathy of prematurity revisited. Arch Ophthalmol. 2005;123:991-999.

5. Vinekar A, Jayadev C, Mangalesh S, et al. Comparing the outcome of single versus multiple session laser photoablation of flat neovascularization in zone 1 aggressive posterior retinopathy of prematurity: a prospective randomized study. Retina. 2015;35(10):2130-2136. doi:10.1097/IAE.0000000000000604

6. Fierson W. American Academy of Pediatrics Section on Ophthalmology, American Academy of Ophthalmology, American Association for Pediatric Ophthalmology and Strabismus, American Academy of Certified Orthoptists. Screening examination of premature infants for retinopathy of prematurity. Pediatrics. 2018;142(6): e20183061. doi:10.1542/peds.2018-3061 
7. Good W; Early Treatment for Retinopathy of Prematurity Cooperative Group. Final results of the early treatment for retinopathy of prematurity (ETROP) randomized trial. Trans Am Ophthalmol Soc. 2004;102:233-248.

8. Hussein M, Coats D, Khan H, et al. Evaluating the association of autonomic drug use to the development and severity of retinopathy of prematurity. $J$ AAPOS. 2014;18(4):332-337. doi:10.1016/j. jaapos.2014.02.012

9. Schmidt B, Roberts RS, Davis P, et al. Caffeine therapy for apnea of prematurity. $N$ Engl J Med. 2006;354(20):2112-2121. doi:10.1056/ NEJMoa054065

10. Schmidt B, Roberts RS, Davis P, et al. Long-term effects of caffeine therapy for apnea of prematurity. $N$ Engl $J$ Med. 2007;357 (19):1893-1902. doi:10.1056/NEJMoa073679

11. Lunt M, Ragab S, Birch A, et al. Comparison of caffeine-induced changes in cerebral blood flow and middle cerebral artery blood velocity shows that caffeine reduces middle cerebral artery diameter. Physiol Meas. 2004;25(2):467-474. doi:10.1088/09673334/25/2/006

12. Hoecker C, Nelle M, Beedgen B, et al. Effects of a divided high loading dose of caffeine on circulatory variables in preterm infants. Arch Dis Child Fetal Neonatal Ed. 2006;91(1):F61-F64. doi:10.1136/adc.2005.073866

13. Tracy MB, Klimek J, Hinder M, et al. Does caffeine impair cerebral oxygenation and blood flow velocity in preterm infants? Acta Paediatr. 2010;99(9):1319-1323. doi:10.1111/j.1651-2227.20 10.01828.x

14. Kearns G, Abdel-Rahman S, Alander S, et al. Developmental pharmacology-drug disposition, action, and therapy in infants and children. $N$ Engl J Med. 2003;349(12):1157-1167. doi:10.1056/ NEJMra035092

15. Lotfi K, Grunwald J. The effect of caffeine on the human macular circulation. Invest Ophthalmol Vis Sci. 1991;32(12):3028-3032.

16. Terai N, Spoerl E, Pillunat L, et al. The effect of caffeine on retinal vessel diameter in young healthy subjects. Acta Ophthalmol. 2012;90 (7):e524-e528. doi:10.1111/j.1755-3768.2012.02486.x

17. Darlow B, Hutchinson J, Henderson-Smart D, et al. Prenatal risk factors for severe retinopathy of prematurity among very preterm infants of the Australian and New Zealand neonatal network. Pediatrics. 2005;114(4):990-996. doi:10.1542/peds.2004-1309

18. Regev R, Lusky A, Dolfin T, et al. Excess mortality and morbidity among small for- gestational-age premature infants: a population-based $\quad$ study. $J \quad$ Pediatr. $\quad 2003 ; 143(2): 186-191$. doi:10.1067/S0022-3476(03)00181-1

19. Sausgtad O. Update on oxygen free radical disease in neonatology. Curr Opin Obstet Gynecol. 2001;13(2):147-153. doi:10.1097/ 00001703-200104000-00009

20. Misra A, Heckford E, Curley A, et al. Do current retinopathy of prematurity screening guidelines miss the early development of pre-threshold type 1 ROP in small for gestational age neonates? Eye. 2008;22(6):825-829. doi:10.1038/sj.eye.6702728

21. Ahn Y, Hong K, Yum H, et al. Characteristic clinical features associated with aggressive posterior retinopathy of prematurity. Eye. 2017;31(6):924-930. doi:10.1038/eye.2017.18

22. Tolsma KW, Allred EN, Chen ML, et al. Neonatal bacteremia and retinopathy of prematurity: the ELGAN Study. Arch Ophthalmol. 2011;129(12):1555-1563. doi:10.1001/archophthalmol.2011.319
23. Abdel HA, Mohamed GB, Othman MF. Retinopathy of prematurity: a study of incidence and risk factors in NICU of Al-Minya University Hospital in Egypt. J Clin Neonatol. 2012;1(2):76-81. doi:10.4103/ 2249-4847.96755

24. Thomas K, Shah PS, Canning R, et al. Retinopathy of prematurity: risk factors and variability in Canadian neonatal intensive care units. J Neonatal Perinatal Med. 2015;8(3):207-214. doi:10.3233/NPM15814128

25. Quinn GE, Johnson L, Abbasi S. Onset of retinopathy of prematurity as related to postnatal and postconceptional age. Br J Ophthalmol. 1992;76(5):284-288. doi:10.1136/bjo.76.5.284

26. Repka MX, Palmer EA, Tung B; For the Cryotherapy for Retinopathy of Prematurity Cooperative Group. Involution of retinopathy of prematurity. Arch Ophthalmol. 2000;118(5):645-649. doi:10.1001/archopht.118.5.645

27. Sahinoglu-Keskek N, Akkoyun I, Torer B. Favorable outcomes in the treatment of aggressive posterior retinopathy of prematurity. Eur J Ophthalmol. 2021;31(1):179-183. doi:10.1177/1120672119886989

28. Kuint J, Barak M, Morag I, et al. Early treated hypotension and outcome in very low birth weight infants. Neonatology. 2009;95 (4):311-316. doi:10.1159/000180113

29. Mizoguchi M, Chu T, Murphy F, et al. Dopamine use is an indicator for the development of threshold retinopathy of prematurity. $\mathrm{Br}$ J Ophthalmol. 1999;83(4):425-428. doi:10.1136/bjo.83.4.425

30. Chen Z, Jia W, Kaufman PL, et al. Immunohistochemical localization of dopamine-beta-hydroxylase in human and monkey eyes. Curr Eye Res. 1999;18(1):39-48. doi:10.1076/ceyr.18.1.39.5391

31. Wu DM, Kawamura H, Li Q, et al. Dopamine activates ATP-sensitive $\mathrm{K}+$ currents in rat retinal pericytes. Vis Neurosci. 2001;18(6):935. doi:10.1017/S0952523801186104

32. Allegaert K, Cossey V, Naulaers G, Vanhole C, Devlieger H, Casteels I. Dopamine is an indicator but not an independent risk factor for grade 3 retinopathy of prematurity in extreme low birthweight infants. Br J Ophthalmol. 2004;88(2):309-310. doi:10.1136/ bjo. 2003.025395

33. Kim SJ, Port AD, Swan R, Campbell JB, Chan RVP, Chiang MF. Retinopathy of prematurity: a review of risk factors and their clinical significance. Surv Ophthalmol. 2018;63(5):618-637.

34. Watts P, Adams GGW, Thomas RM, Bunce C. Intraventricular haemorrhage and stage 3 retinopathy of prematurity. $\mathrm{Br} J$ Ophthalmol. 2000;84(6):596-599. doi:10.1136/bjo.84.6.596

35. Waheeb S, Alshehri K. Incidence of retinopathy of prematurity at two tertiary centers in Jeddah, Saudi Arabia. Saudi J Ophthalmol. 2016;30(2):109-112. doi:10.1016/j.sjopt.2016.02.006

36. Yau GS, Lee JW, Tam VT, et al. Incidence and risk factors of retinopathy of prematurity from 2 neonatal intensive care units in a Hong Kong Chinese population. Asia Pac J Ophthalmol. 2016;5 (3):185-191. doi:10.1097/APO.0000000000000167

37. Lundgren P, Lundberg L, Hellgren G, et al. Aggressive posterior retinopathy of prematurity is associated with multiple infectious episodes and thrombocytopenia. Neonatology. 2017;111(1):79-85. doi:10.1159/000448161 


\section{Publish your work in this journal}

Clinical Ophthalmology is an international, peer-reviewed journal covering all subspecialties within ophthalmology. Key topics include: Optometry; Visual science; Pharmacology and drug therapy in eye diseases; Basic Sciences; Primary and Secondary eye care; Patient Safety and Quality of Care Improvements. This journal is indexed on PubMed
Central and CAS, and is the official journal of The Society of Clinical Ophthalmology (SCO). The manuscript management system is completely online and includes a very quick and fair peer-review system, which is all easy to use. Visit http://www.dovepress.com/ testimonials.php to read real quotes from published authors. 